\title{
Phytoplankton blooms in the Urdaibai estuary during summer: physico-chemical conditions and taxa involved
}

\author{
Emma ORIVE*, Arantza IRIARTE, Iosu DE MADARIAGA, Marta REVILLA \\ Laboratorio de Ecología, Facultad de Ciencias, Universidad del País Vasco, Apdo. 644, 48080 Bilbao, Spain
}

(Revised 19/09/97, accepted 23/09/97)

\begin{abstract}
In the Urdaibai estuary, despite its small volume in relation to the tidal prism, phytoplankton grows massively in the upper and intermediate zones of the estuary during summer when rainfall is low to moderate. Data obtained in 23 sampling transects along the longitudinal axis of the estuary, undertaken in July 1993 and August 1994, showed three distinct zones in terms of the phytoplankton species composition: in the upper zone the phytoplankton assemblage was dominated by the diatoms Cyclotella spp., the dinoflagellate Glenodinium foliaceum, cryptophytes and euglenophytes; in the intermediate zone the diatom Chaetoceros ceratosporus, the dinoflagellates Peridinium quinquecorne and Prorocentrum minimum and cryptophytes were the most abundant; in the lower zone diatoms such as Leptocylindricus danicus and Skeletonema costatum together with the dinoflagellates Prorocentrum spp. were dominant. The distribution and abundance of these phytoplankton forms is discussed in relation to variations in salinity, water column stratification, nutrients and temperature, which in turn vary mainly as a function of meteorological conditions (i.e. rainfall, irradiance) and tidal amplitude. The longitudinal distribution of phytoplankton cells suggests that the diatoms Cyclotella spp. and Chaetoceros ceratosporus undergo a greater dispersion along the estuary during rain events than the flagellates, thus contributing to the transport of silica to the outer areas of the estuary. (C) Elsevier, Paris
\end{abstract}

\section{phytoplankton / hydrography / nutrient / Urdaibai estuary}

Résumé - Floraisons estivales du phytoplancton dans l'estuaire de Guernica : conditions physico-chimiques et taxons. L'Estuaire de Guernica dans le pays basque, est de faible volume en comparaison avec les eaux déplacées par la marée ; pourtant en été, lorsque les précipitations sont faibles à modérées, le phytoplancton s'y développe en abondance dans les secteurs amont et intermédiaire. La composition taxonomique des prélèvements effectués en juillet 1993 et août 1994, suivant l'axe longitudinal de l'estuaire, révèle trois secteurs. L'amont est dominé par la diatomée du genre Cyclotalla spp., le dinoflagellé Glenodinium foliaceum, les cryptophycées et les euglenophycées. Dans le secteur intermédiaire, la diatomée Chaetoceros ceratosporus est en abondance, avec les dinoglagellés Peridinium quinquecorne et prorocentrum minimum et les cryptophycées. En aval, les diatomées telles que Leptocylindrus danicus et Skeletonema costatum sont dominantes, associées au dinoflagellé Prorocentrum spp. La répartition et l'abondance de ces espèces est discutée en relation avec la salinité, la stratification des eaux, les nutriments et la température, paramètres qui varient eux-mêmes avec les conditions météorologiques (précipitations, éclairement) et l'amplitude de la marée. La répartition longitudinale du phytoplancton suggère que, pendant les précipitations, les diatomées de Cyclotella spp. et Chaetoceros ceratosporus sont soumises à une plus grande dispersion que les dinoflagellés, contribuant ainsi au transfert de silice en dehors de l'estuaire. (C) Elsevier, Paris

\section{phytoplancton / hydrologie / nutriment / estuaire de Guernica}

\footnotetext{
* Correspondence and reprints
} 


\section{INTRODUCTION}

Differences in the geomorphology, hydrology and land uses of the basin preclude generalisations on phytoplankwn distribution patterns in estuaries. These ecosystems show a higher nutrient availability than adjacent coastal waters and, if the water residence time in the cstuary is high enough and turbidity is low, phytoplankton can grow massively $[2,4]$. Furthermore, zooplankton populations recover more slowly than phytoplankton after having been washed out of the estuary or of their salinity optimum by heavy freshwater discharges, thus favouring phytoplankton biomass accumulation in the estuary under these conditions.

The spatial distribution of the phytoplankton biomass maxima varies among estuaries mainly as a function of the magnitude and position of the turbidity maximum, water column stratification, nutrient availability and grazing rates $[5,7]$. The sediment type also plays a role, since many estuarine species with benthic resting forms base their survival strategy on the ability to reach the sediment quickly, thus avoiding being washed out of the estuary by currents [24].

In each estuary the spatial distribution of phytoplankton biomass varies mainly as a function of the relative importance of the tidal amplitude and the freshwater discharges, which are two of the parameters with greater influence on physico-chemical variables that are relevant for phytoplankton growth and accumulation, such as nutrient concentration, light availability and water column stratification $[3,4]$.

In general, it is a single species or a few species which are responsible for these phytoplankton biomass peaks, and estuaries differ among themselves not only in terms of the location of these peaks, but also in the algal taxa that dominate each of them [22]. Furthermore, it is increasingly recognised that the role of phytoplankton in the biogeochemical cycles and in the trophic interactions is highly species-specific and, therefore, a need for investigating the factors that determine the taxonomic composition of phytoplankton blooms has been identified [4].

The aim of the present study was to determine which are the dominant phytoplankton taxa that grow in the Urdaibai estuary during summer and to investigate the physico-chemical conditions that favour their accumulation in different zones of the estuary.

\section{STUDY AREA}

The Urdaibai estuary (also known as Gernika or Mundaka estuary) is a meso-macrotidal estuary located in the Basque country, north of Spain $\left(13^{\circ} 22^{\prime} \mathrm{N}, 2^{\circ} 40^{\prime} \mathrm{W}\right)$ (figure 1). According to differences in tidal and river influence, three sections can be distinguished in the estuary. The outer estuary is characterised by salinity values generally higher than 31 and a well mixed water column, except during periods of very heavy freshwater discharges, when a very weak stratification might be observed. The estuary is widest and has the largest volume in this outer zone, where extensive sand flats (in the outer half) and sand-mud flats (in the inner half) become exposed at low tide. Tidal flushing is elevated in this zone. In the intermediate section, salinity values generally range between 25 and 31 and the water column shows some stratification. In this area extensive salt marshes have developed, occupying areas of limited tidal influence. In the inner section of the estuary, a narrow artificial channel (about $15 \mathrm{~m}$ wide) of muddy bed extends up to the town of Gernika. This inner zone shows a marked riverine influence and salinity varies considerably as a function of river flow and tidal condition. The water column is generally partially mixed and tidal flushing is limited. Under conditions of heavy freshwater discharges at the inner zone the water column is well mixed [23].

The freshwater residence time in the estuary varies between $<1$ day with high discharges and $>60$ days during prolonged dry periods, when river flow can reach values of $50 \mathrm{~L} \cdot \mathrm{s}^{-1}$.

\section{MATERIALS AND METHODS}

Data presented in this article were obtained during two studies on plankton metabolism undertaken in the estuary in July 1993 and August $1994[14,20]$.

In July 1993, sampling was carried out from 3 to 15 July, with daily surveys at three stations (1, 3 and $5 *$ ) located in the outer, intermediate and inner sections of the estuary, respectively (figure 1). In 1994, surveys werc performed approximately every 2 nd day from 3 to 22 August and samples were taken at four stations located also in the outer (station 1), intermediate (station 3) and inner (stations 5 and 7) sections of the estuary (figure I). All samplings were carried out at high tide. 


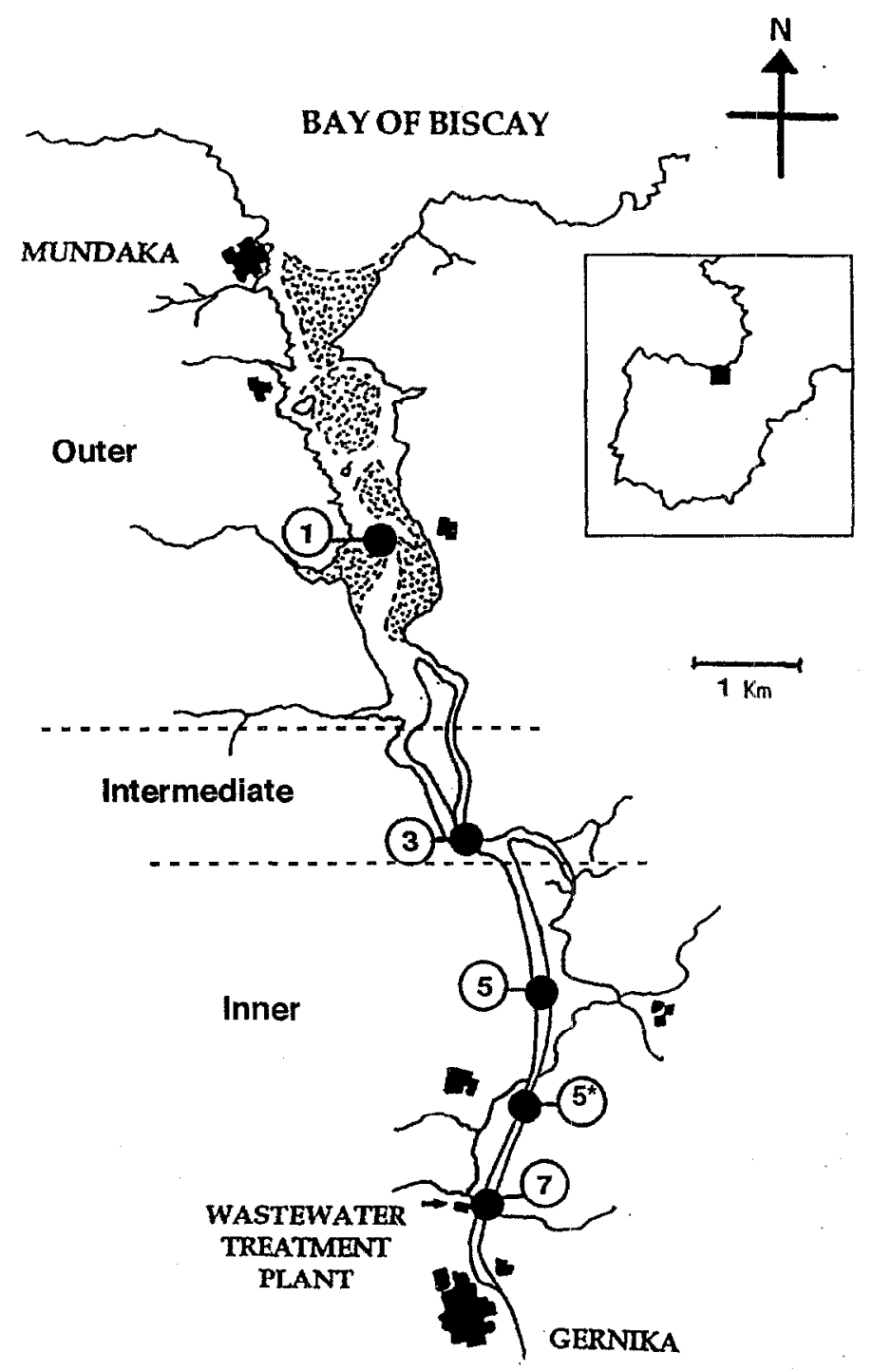

Figure 1. Study area and sampling sites. Stations 1, 3 and $5 *$ were sampled in July 1993 and stations 1, 3, 5 and 7 in August 1994.

At each station, vertical profiles of temperature and salinity were obtained using a specific sensor (WTW instruments model LF191 LT1/T) that was calibrated just before each survey, and subsurface water samples wcre taken for nutrient and chlorophyll $a$ analyses and phytoplankton identification and counting. Secchi disk depths were also registered and light extinction coefficients were determined according to Madariaga [19]. The coefficient of stratification of the water column was calculated as the ratio between the difference in salinity between surface and bottom and the depth of the water column [32]. Water samples were preserved in Lugol's iodine and, after sedimentation of 25 or $50 \mathrm{~mL}$ (depending on chlorophyll $a$ and detritus concentrations), phytoplankton was identified and counted using an invertcd Nikon microscope, counting at least 400 cells of the dominant forms. Phytoplankton species that were observed in low densities have not been dealt with in the present study.

For cell counts of diatoms of the genus Cyclotella, it has not been possible to distinguish among the different species, because for identification down to the level of spe- 
cies cells must be devoid of their organic content in order to be able to observe the details of their siliceous cell wall. Detailed ultrastructural examinations revealed that C. atomus, C. glomerata and C. meneghiniana f. comta were the most abundant forms (Derek Harbour, personal communication).

Duplicate water samples were filtered onto Whatman GF/ F filters and chlorophyll a concentration was determined spectrophometrically in $90 \%$ acetone extracts, using the equations of Jeffrey and Humphrey [16]. Nitrate, nitrite, ammonia, phosphate and silicate were determined using standard colorimetric methods [35]. Rainfall data were provided by the Centro Meteorológico Territorial del País Vasco.

\section{RESULTS}

\subsection{Abiotic parameters}

\section{I.1. July 1993}

During the study period, several short but intense pulses of rain were registered at intervals of 3 to 4 days and tidal amplitudes denoted spring tides during the first half of the study period and neap tides during the second half (figure 2).

In the outer section of the estuary, exhibiting euhaline characteristics (figure 3), the water column showed peri- ods of slight stratification and periods of mixing (figure 4). Nutrient concentrations were relatively low (table $I$ ) and temperatures (around $20^{\circ} \mathrm{C}$ ) were less variable than in the mid and upper zones of the estuary (figure 2).

Nutrient concentrations, particularly of silicate, were considerably higher in the intermediate section (table o) and although the water column, with meso-polyhaline characteristics (figure 2), showed a variable degree of stratification, it was generally partially mixed (figure 3). The coefficient of stratification increased with the rain pulses (figure 3).

The inner section was oligohaline during the rain pulses, with salinities around 1, and changed to mesohaline when the freshwater discharge decreased (figure 2). In this zone, the water column was partially mixed during the entire period of study (figure 3) and stratification also increased as a result of the enhanced river flow. Nutrient concentrations in this section reached levels typical of highly eutrophic areas (table $l$ ).

Light extinction coefficient values increased from the outer to the inner estuary, varying mainly as a function of rainfall and tidal amplitude (figure 2).

\subsubsection{August 1994}

A first intense rain pulse was registered at the beginning of the study period, and a second, much more moderate

Table 1. Range and mean values of inorganic nutrients and chlorophyll $a$ in surface waters.

\begin{tabular}{|c|c|c|c|c|}
\hline \multicolumn{5}{|c|}{ July 1993} \\
\hline Stations & 1 & 3 & $5^{*}$ & \\
\hline Nitrate $(\mathrm{mM})$ & $5.22(0.66-14.77)$ & $28.10(11.83-52.95)$ & $56.61(31.99-105.08)$ & \\
\hline Nitrite (mM) & $0.13(0.04-0.24)$ & $0.98(0.74-1.30)$ & $1.68(1.04-2.42)$ & \\
\hline Ammonia (mM) & $2.02(0.64-4.03)$ & $21.76(0.52-40.15)$ & $68.32(25.03-119.36)$ & \\
\hline Phosphate (mM) & $0.31(0.20-0.45)$ & $0.89(0.28-2.01)$ & $5.65(1.99-12.59)$ & \\
\hline Silicate $(\mathrm{mM})$ & $2.55(0.29-5.89)$ & $37.40(22.75-56.47)$ & $105.49(90.12-126.34)$ & \\
\hline $\operatorname{Chl} a(\mathrm{mg} / \mathrm{L})$ & $2.5(1.0-5.6)$ & $11.7(4.1-30.9)$ & $20.1(3.6-84.3)$ & \\
\hline \multicolumn{5}{|c|}{ August 1994} \\
\hline Stations & 1 & 3 & 5 & 7 \\
\hline Nitrate $(\mathrm{mM})$ & $1.39(\mathrm{ud}-3.07)$ & $5.40(1.31-11.98)$ & $19.05(13.60-37.57)$ & $26.21(13.29-58.90)$ \\
\hline Nitrite $(\mathrm{mM})$ & $0.15(0.03-0.29)$ & $0.77(0.18-1.61)$ & $3.16(1.89-4.89)$ & $3.10(2.45-3.87)$ \\
\hline Ammonia (mM) & $2.68(0.21-6.90)$ & $9.65(0.10-27.19)$ & $50.34(16.66-108.95)$ & $279.63(122.56-432.79)$ \\
\hline Phosphate (mM) & $0.23(\mathrm{ud}-1.19)$ & $0.56(\mathrm{ud}-1.88)$ & $3.91(1.72-7.78)$ & $26.10(13.57-38.99)$ \\
\hline Silicate $(\mathrm{mM})$ & $0.42(0.08-1.09)$ & $1.87($ ud -4.34$)$ & $9.50(5.71-15.30)$ & $21.31(15.50-32.53)$ \\
\hline Chl $a(\mathrm{mg} / \mathrm{L})$ & $2.1(0.0-4.4)$ & $11.2(2.6-43.4)$ & $16.8(5.9-33.5)$ & $32.2(12.4-78.1)$ \\
\hline
\end{tabular}

ud: undetected. 

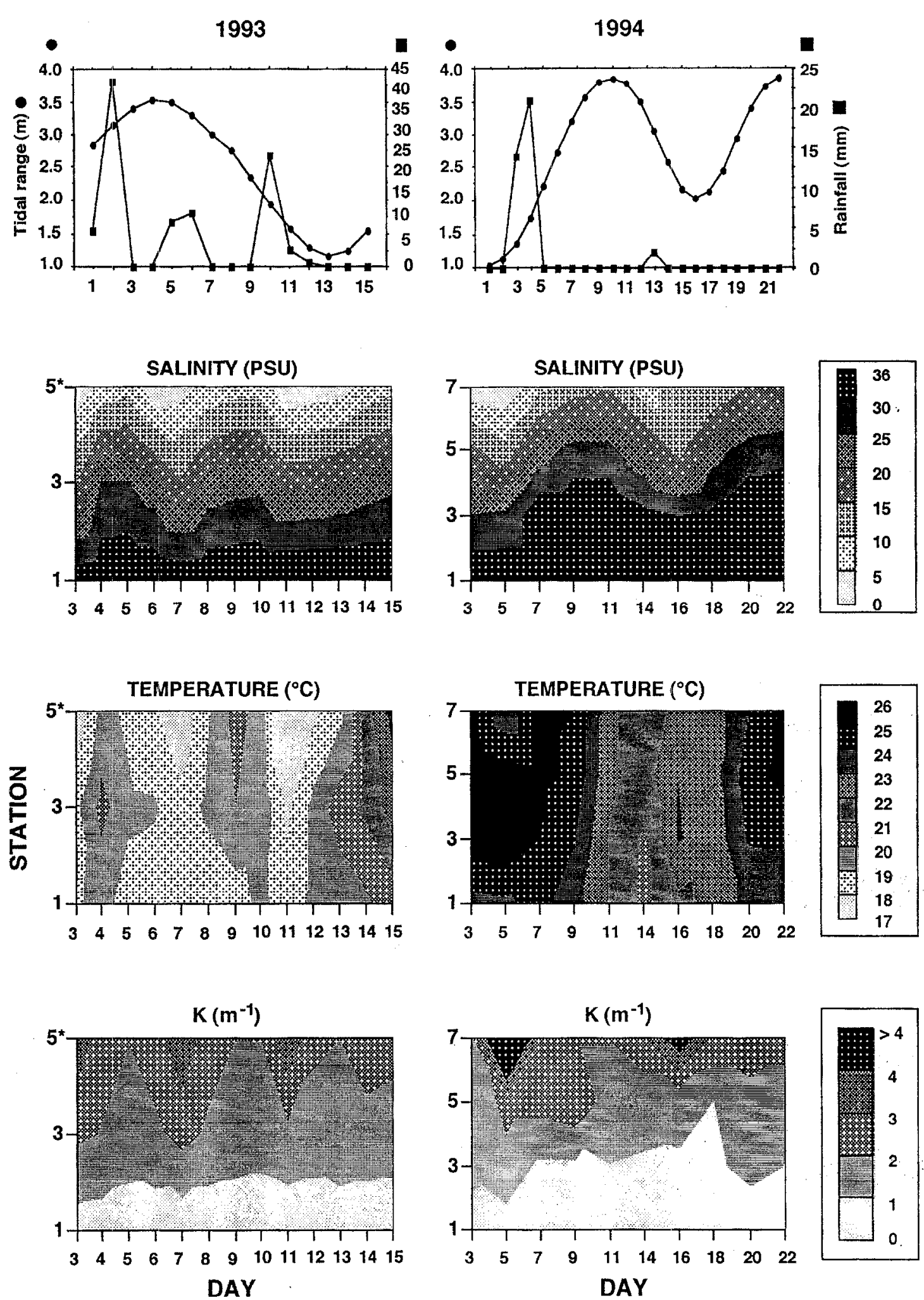

Figure 2. Temporal variation of tidal amplitude and rainfall and longitudinal and temporal variation of surface salinity, temperature and light extinction coefficients. 

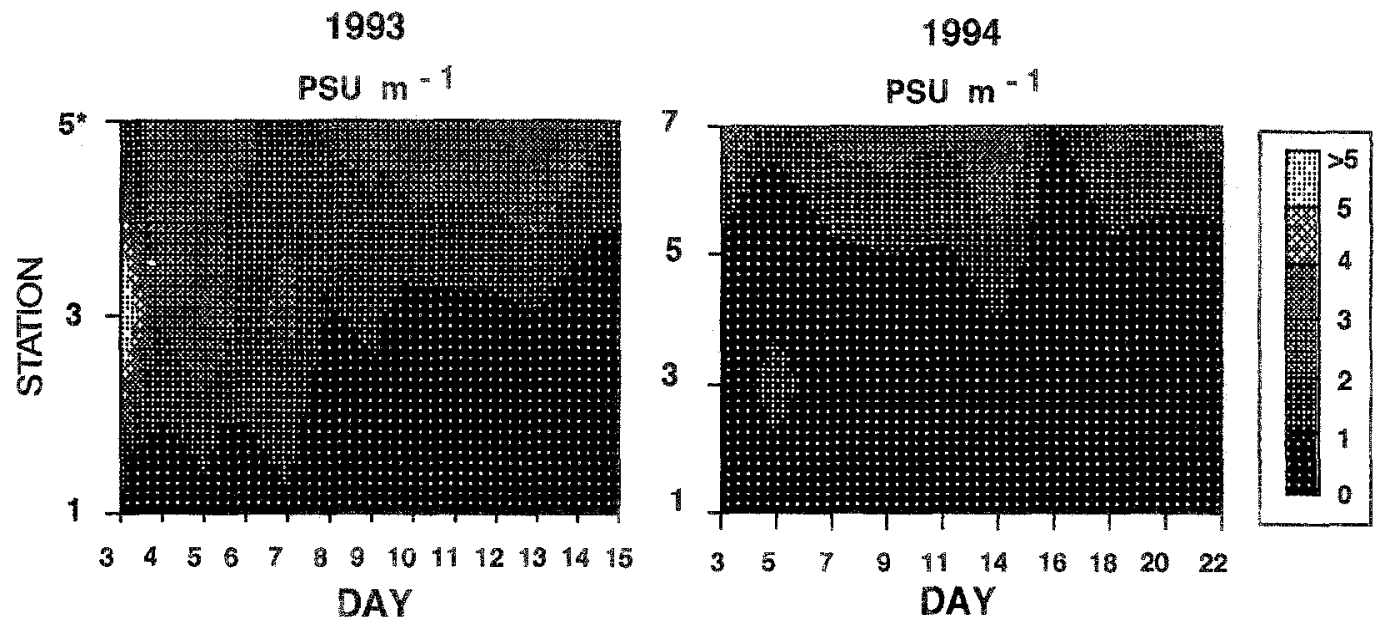

Figure 3. Spatial and temporal variation of the coefficient of stratification.

one on 13 and 14 August (figure 2). Salinity values were higher than during the 1993 period of study and the intermediate section showed poly-euhaline characteristics instead of the meso-polyhaline ones of the previous year, while station 5 was meso-polyhaline (figure 2). At the outer estuary, the water column was well mixed for the entire period of study, the intermediate zone showed a slight stratification during neap tides and the inner estuary was generally stratified (figure 3). Temperature also showed marked variations, ranging from 20.4 to $26.2{ }^{\circ} \mathrm{C}$, values being, in general, higher than in July 1993 (figure 2). Inorganic nutrient concentrations decreased sharply in the offshore direction and values, particularly for nitrate and silicate, were considerably lower than during the July 1993 surveys (table 1). The pattern of variation of the light extinction coefficient was similar to that observed in July 1993 (figure 2).

Data from both years at stations $5,5^{*}$ and 7 showed that the depth of the photic zone, i.e. the depth of $1 \%$ surface incident irradiance, was always greater than the depth of the surface mixed layer, except on three occasions, two of which were days of elevated river flow (figure 4).

\subsection{Spatial changes and temporal succession of phy- toplankton}

\subsubsection{July 1993}

In July 1993, two peaks of chlorophyll a (concentrations $>60 \mu \mathrm{g} \operatorname{chl} a \mathrm{~L}^{-1}$ ) were registered at stations 3 and $5 *$ on days 9 and 15. Both peaks were preceded by several days without rainfall (table 1, figure 2). In the outer estuary (station 1), mainly marine in character, the diatom Leptocylindricus danicus was dominant for most of the study period, reaching a maximum density of $10.9 \times 10^{5}$ cells. $\mathrm{L}^{-1}$ on day 8 (figure 5). The distribution of this species was restricted almost exclusively to the outer zone. Occasionally, elevated densities of small, unidentified flagellates and small diatoms of the genera Cyclotella and Chaetoceros ( $<10 \mu \mathrm{m}$ in diameter) were also registered. In general, in this outer zone phytoplankton was scarce and chlorophyll $a$ concentration was $<6 \mu \mathrm{g} \cdot \mathrm{L}^{-1}$. Total phytoplankton cell density was higher than in areas further up the estuary only on days following the rainfalls of 10 and 11 July (figure 7), which coincided with neap tides, suggesting advective transport of phytoplankton in the offshore direction as responsible for this outer peak. Ancillary data comparing rates of primary production and phytoplankton abundance further showed that these cells that were transported to the outer zone of the estuary (mainly nanoplanktonic cells of the genus Cyclotella) were not growing actively [20].

In the intermediate estuary (station 3 ) the diatom Chaetoceros ceratosporus was dominant during near spring tides, reaching densities of $11.5 \times 10^{6}$ cells $\cdot L^{-1}$ on day 9 (figure 5). During neap tides cryptophytes and small flagellates increased in density, attaining maxima of $2.7 \times$ $10^{6}$ and $4.8 \times 10^{6}$ cells $\mathrm{L}^{-1}$, respectively, at the end of the study period (figure 5). On day 15, a peak of the dinoflagellate Peridinium quinquecorne $\left(7.3 \times 10^{5}\right.$ cells $\cdot \mathrm{L}^{-1}$ ) was registered, together with high densities of 


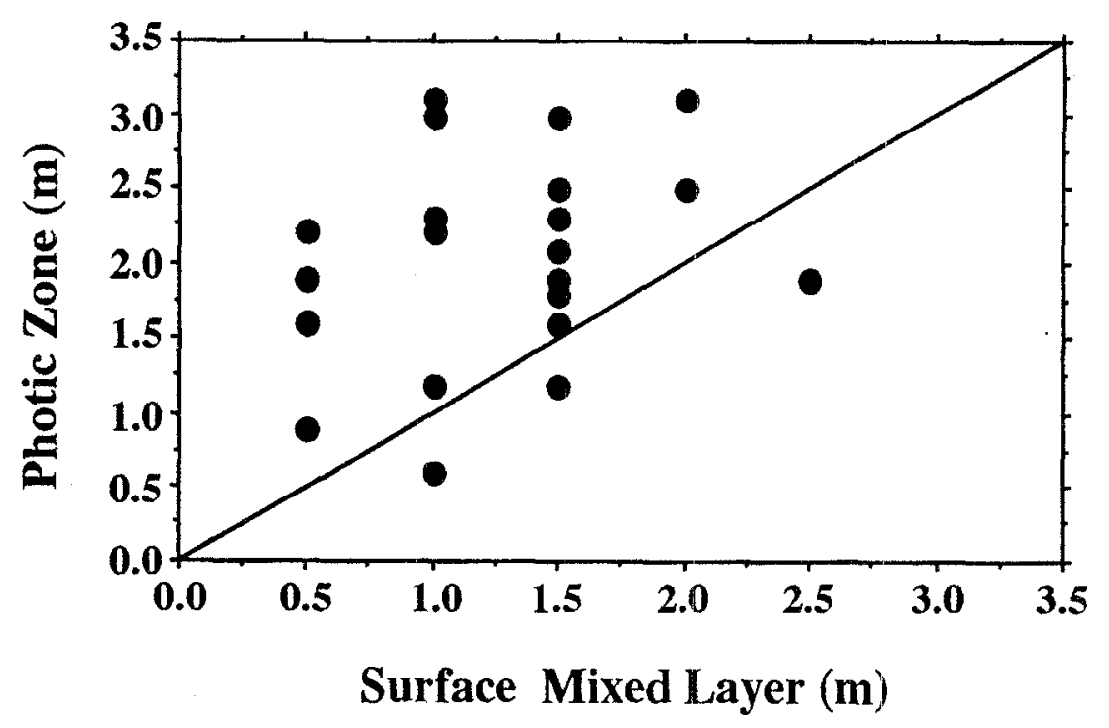

Figure 4. Relationship between the depth of the photic zone and the depth of the surface mixed layer at stations $5,5^{*}$ and 7.

cryptophytes, euglenophytes and unidentified small flagellates (figure 5).

In the inner estuary (station $5^{*}$ ), phytoplankton only attaincd clevated densitics when salinitics reached the mesohaline range. Diatoms of the genus Cyclotella (maximum concentration of $5 \times 10^{6}$ cells $\cdot \mathrm{L}^{-1}$ ) dominated over the first half of the study period and cryptophytes and the dinoflagellate Glenodinium foliaceum during neap tides (figure 5).

The total number of phytoplankton cells was maximum in the intermediate zone during spring tides and the spring/neap transition (figure 7), due mainly to the elevated density of the diatom Chaetoceros ceratosporus. Later, during neap tides and rain events, phytoplankton populations were shifted towards the outer zone of the estuary. On days 11, 12 and 13, maximum phytoplankton cell density was measured at station 1 . At the end of the study period, under conditions of atmospheric stability and neap tides, the total number of cells peaked at the inner estuary on day 14 , due to the massive accumulation of Glenodinium foliaceum, cryptophytes and small flagellates and in the intermediate estuary on day 15 , due to the growth of Peridinium quinquecorne, cryptophytes, euglenophytes and unidentified small flagellates.

\subsubsection{August 1994}

In August 1994 phytoplankton biomass was generally highest at the inner estuary, with a maximum value of
$78.1 \mu \mathrm{g}$ chl $a \mathrm{~L}^{-1}$ (station 7) on 14 August, although on 3 August the highest concentration of chlorophyll $a$ $\left(43.6 \mu \mathrm{g} \cdot \mathrm{L}^{-1}\right)$ was detected at station 3 (table I).

At the outer estuary (station 1) the diatom Skeletonema costatum was the dominant species, attaining a maximum density of $8.9 \times 10^{5}$ cells $\cdot L^{-1}$, during the first rain event (figure 6). The species remained at this station for the entire period of study, but at salinities higher than 30 it appeared in low concentration and together with neritic species, mainly dinoflagellates of the genus Prorocentrum and small flagellates (figure 6).

Phytoplankton density was low at station 3 under euhaline conditions, and included a contingent of both neritic and estuarine species, in which Skeletonema costatum was the most abundant (figure 6). When salinities ranged in the polyhaline interval, which was observed during neap tides at the very beginning of the study period, a rich community of small flagellates together with elevated densities of Peridinium quinquecorne and Prorocentrum minimum were observed (figure 6 ).

At station 5, under conditions of neap tides and salinity values between 15 and 20, cryptophytes and the dinoflagellate Prorocentrum minimum were the most abundant forms, whereas at salinities between 25 and 30 small flagellates and Peridinium quinquecorne appeared as dominant forms (figure 6). At salinities below 15, phytoplankton was very scarce. During spring tides of about $4 \mathrm{~m}$, and under conditions of slight water column stratifi- 

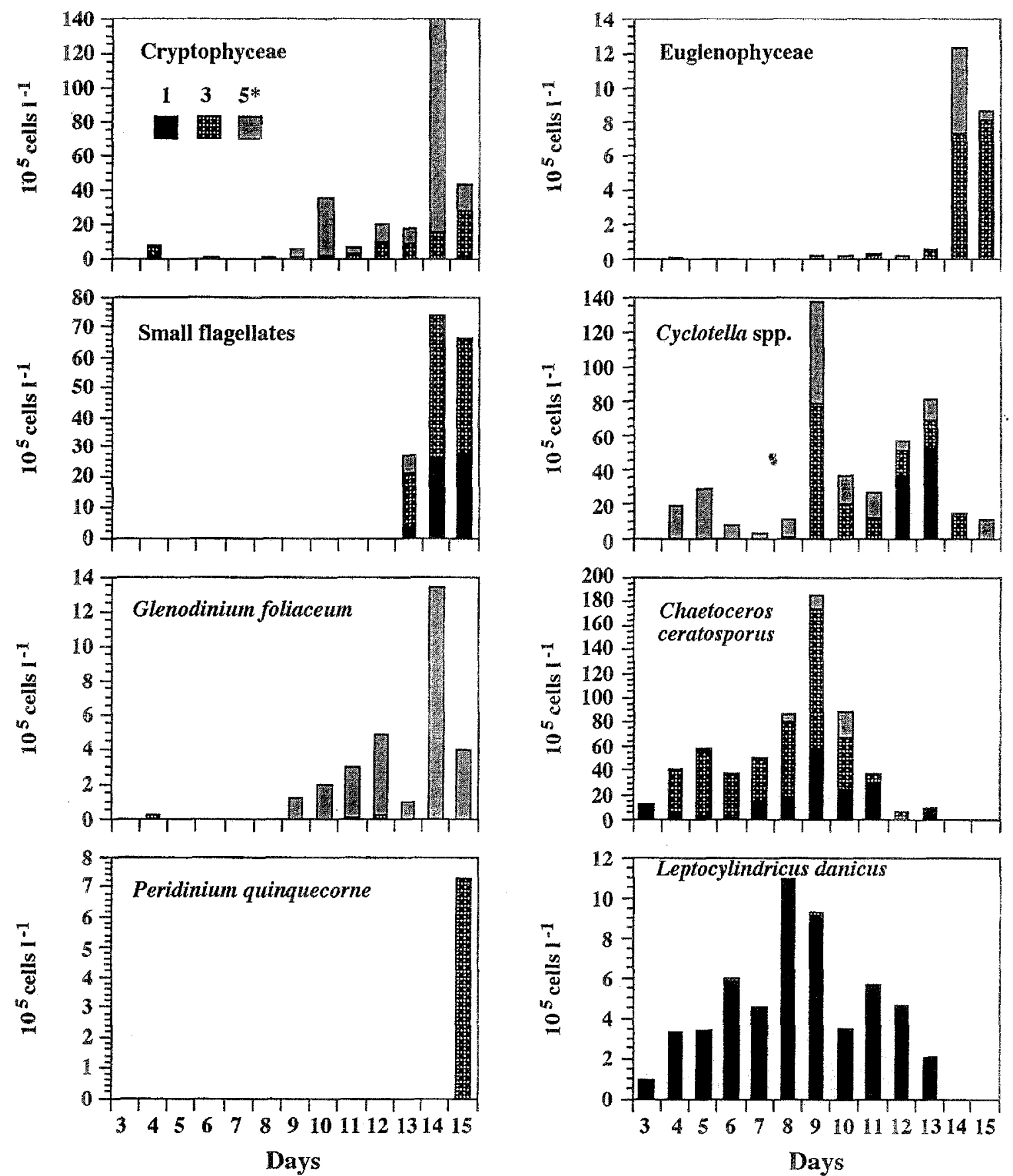

Figure 5. Distribution of selected phytoplankton taxa at stations 1,3 and $5^{*}$ during the study period conducted in July 1993 .

cation, $P$. quinquecorne attained a maximum density of $4.1 \times 10^{6}$ cells $\cdot L^{-1}$. This species shifts from site 3 lo site 5 at spring tides when both salinity and tidal flushing increase at the intermediate estuary (figure 6). At the end of the study period, during a transition from neap to spring tides and under stable weather conditions, increased concentrations of the diatoms Chaetoceros ceratosporus and Cyclotella spp. were detected (figure 6). 

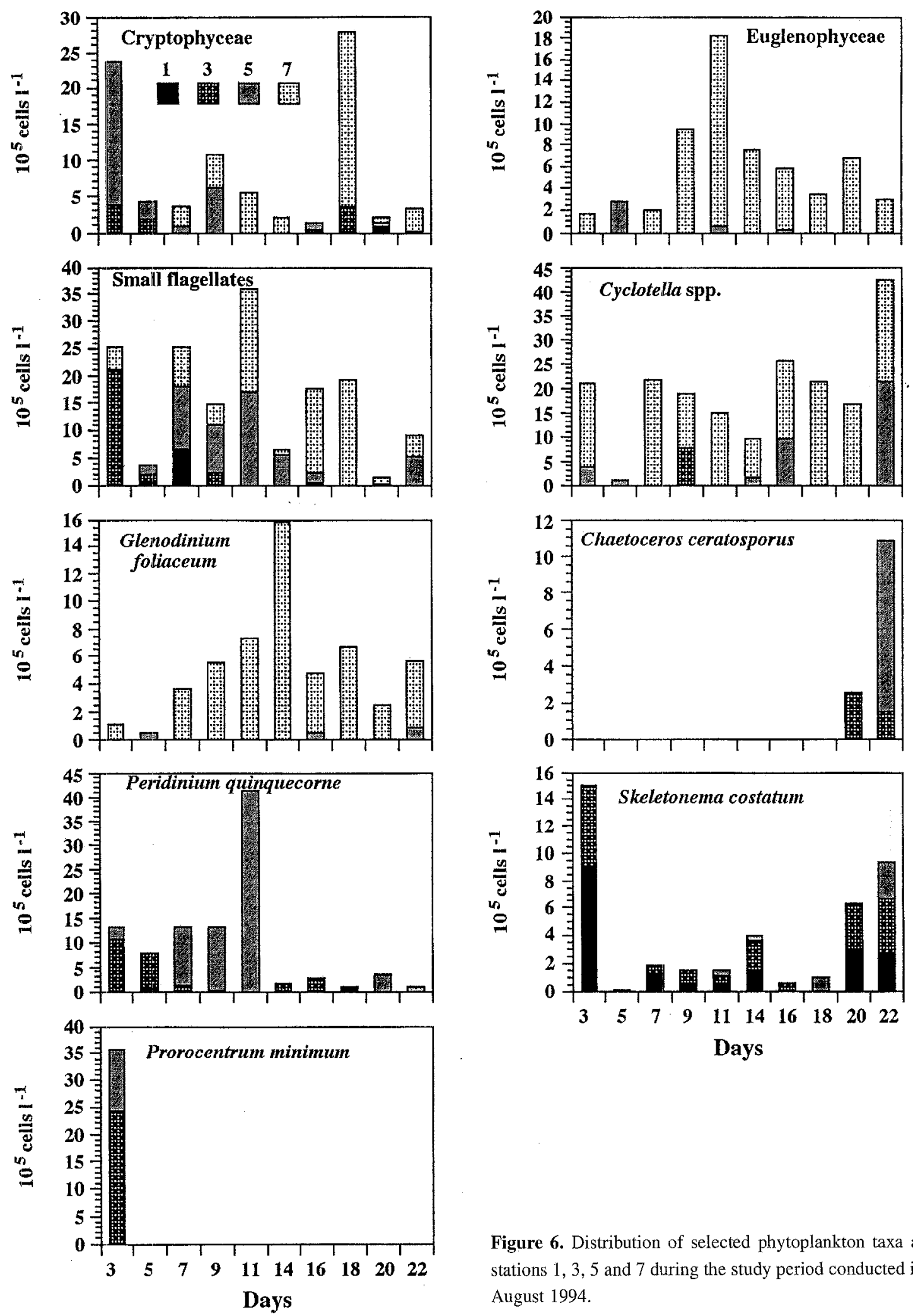

Figure 6. Distribution of selected phytoplankton taxa at stations $1,3,5$ and 7 during the study period conducted in August 1994. 
At station 7, phytoplankton density was high throughout the entire period of study, ranging from $2.5 \times 10^{6}$ to $7.5 \times$ $10^{6}$ cells $\cdot L^{-1}$ (figure 7). Minimum values were recorded during the rain events, when salinity was below 5 . When salinity ranged between 5 and 15 , the dominant species were diatoms of the genus Cyclotella and the dinoflagellate Glenodinium foliaceum, together with cryptophytes, euglenophytes and other unidentified small flagellates (figure 6 ). The maximum concentration of $G$. foliaceum $\left(1.5 \times 10^{6}\right.$ cells $\left.\cdot L^{1}\right)$ was recorded on 14 August, coinciding with the highest value of chlorophyll $a$ registered in the estuary during the study period. The total number of phytoplankton cells was much higher in the inner zone of the estuary than in the intermediate and outer zones, except during the rain events that occurred at the very beginning of the study period, when the maximum number of cells was measured at the intermediate estuary (figure 7 ).

\section{DISCUSSION}

Tides and freshwater discharges play a major role in the distribution of phytoplankton in estuaries. In the Urdaibai estuary in summer, phytoplankton biomass and density peak in the upper zone of the estuary during periods of low to moderate freshwater discharge. This is a feature common to many other estuaries, where the increased water residence time and the decreased turbidity that occur during low discharges promote phytoplankton growth and accumulation $[15,27,31]$. Although turbidity can at times be high in the upper section of the Urdaibai estuary, during periods of low to moderate freshwater discharge the photic zone extends deeper than the surface mixed layer due to the stratification of the water column, which allows us to conclude that turbidity is not a limiting factor for phytoplankton growth in summer.

The dominant diatoms in the upper zone of the Urdaibai estuary belong to the Cyclotella genus and were found in waters of salinities in the $5-15$ range. In this zone lower salinities were only measured during heavy rain events, when the low residence time of the water was presumably limiting phytoplankton accumulation. These small diatoms have been found in a variety of aquatic habitats, but more frequently in lower zones of rivers and in upper zones of estuaries $[1,6,8,15,18,28]$. They seem to be able to maintain themselves in these habitats due to a thick siliccous shcath that allows them to sink to the bottom rapidly [33]. They can return to the water column by. sediment resuspension events. In the Urdaibai estuary during dry calm periods, sediment resuspension has been observed in the upper zone of the estuary at floods during spring tides [29]. Nutrient availability and turbidity are not limiting for the growth of these diatoms in the upper estuary. Data suggest that it is mainly the water residence time which controls variations in the biomass of these
1993

$10^{6}$ cells $^{-1}$

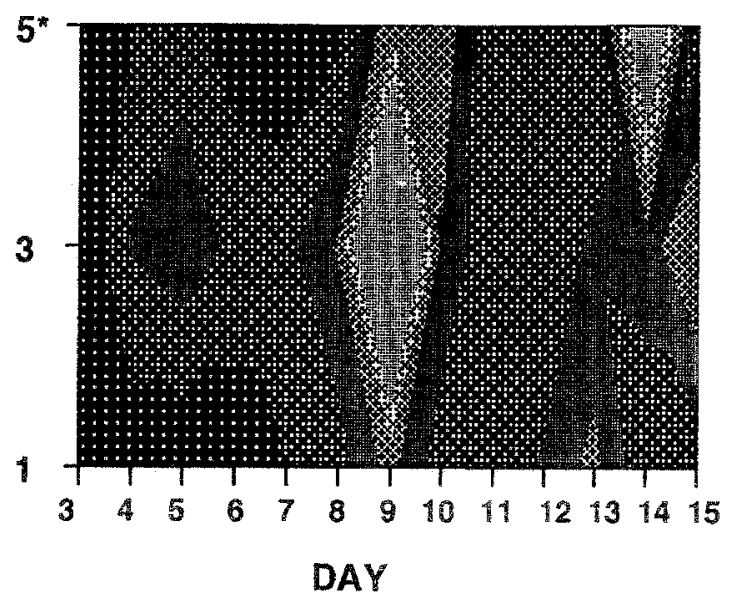

1994
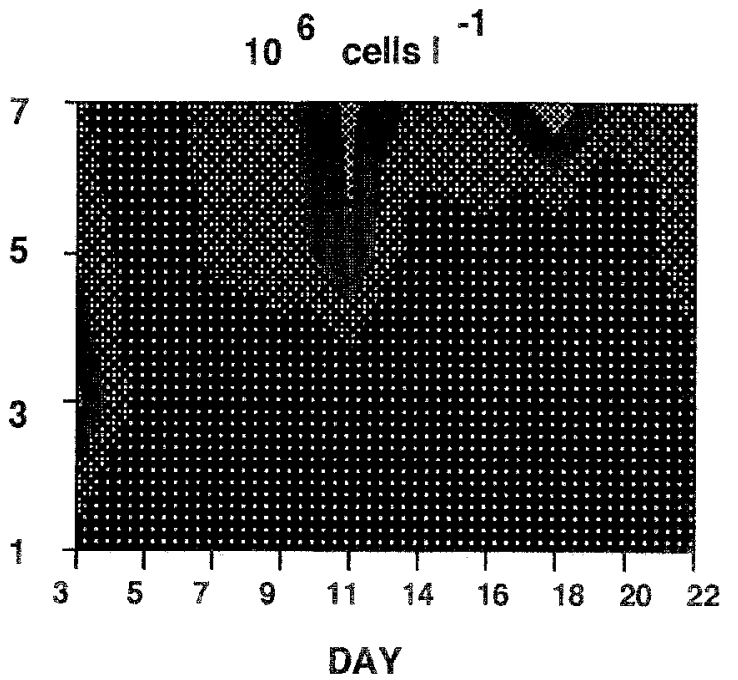

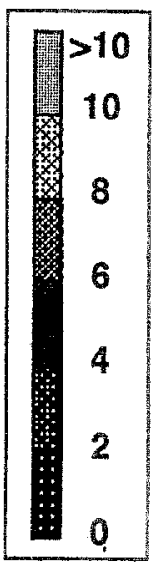

Figure 7. Spatio-temporal distribution of total phytoplankton cell concentration (i.e. sum of taxa presented in figures 5 and 6 ) 
diatoms in the upper estuary. During heavy rain events, Cyclotella spp. have been shown to be swept away from the upper zone more easily than the flagellates, particularly the dinoflagellates, which are rarely found outside their optimum salinity range. These diatoms, therefore, represent an extra source of silicate for lower zones of the estuary.

The dinoflagellate Gienodinium foliaceum is also a species characteristic of the upper zone of the estuary. It accumulates at higher salinities (10-18) than the diatoms of the genus Cyclotella and it requires a more stratified water column. G. foliaceum has also been observed in the meso-polyhaline region of other small shallow estuaries of the Basque coast, where it has been found to reach cell densities higher than $6 \times 10^{6}$ cells $\cdot L^{-1}$ in summer [13]. According to Jenkinson [17], this dinoflagellate shows a preference for high temperatures and it is usually found in high concentrations during summer.

Cryptophytes reached densities higher than $12 \times 10^{6}$ cells. $\mathrm{L}^{-1}$ in the upper estuary and were more abundant during neap tides, whereas euglenophytes were present more or less constantly at station 7 , co-dominating with Glenodinium foliaceum and/or Cyclotella spp.

Nutrient availability and the relatively low residence time of the water in summer favour phytoplankton growth and accumulation in the upper estuary. Furthermore, the dominant species seem to have the capacity to remain in the estuary, by passive sinking in the case of the heavily silicified diatoms, and by active vertical migration in the case of Glenodinium foliaceum and Peridinium quinquecorne. Plots of nutrients versus salinity suggest that a large part of the nutrients are consumed in the upper estuary [23].

Estuarine fronts are zones of phytoplankton accumulation [36]. In the Urdaibai estuary, the front was generally located in the intermediate zone (station 3) $[14,21]$, where during spring tides and salinities between 25 and 30, elevated densities of Chaetoceros ceratosporus were observed. This diatom does not seem to be the optimum food for zooplankton [9]: probably due to its siliceous setae, a fact that would partly explain the elevated densities that this diatom attains in the estuary.

Peridinium quinquecorne is another species that occupies this intermediate zone, both during neap tides and during spring/neap transitions. It is observed mainly in the 25-30 salinity range. This species has been found in other estuaries, generally under conditions of high temperatures [11] and has been observed to accumulate in a near-surface layer during flood tides, disappearing to a great extent from this layer shortly before high tide [12]. Because during the present study water samples were taken from the subsurface at high tide, it is likely that $P$. quinquecorne attains even higher densities than those measured here. In August 1994, the maximum concentration of this species was measured at station 5 , because waters of salinities between 25 and 30 reached further up the estuary than during the July 1993 survey.

The absence of Chaetoceros ceratosporus in the estuarine front zone in 1994 during spring tides of 9-11 August could be due to the higher temperature of the water during the 1994 sampling, which seems to favour the growth of Peridinium quinquecorne, and to the lower concentration of silicate. These lower concentrations of silicate were a consequence of the less intense rainfalls that were registered in 1994. Chaetoceros ceratosporus, however, appeared during the second transition from neap to springs (2-22 August), but in relatively low concentrations, probably due to a silicate supply to the estuary that was observed between days 14 and 16 [14].

Prorocentrum minimum is a dinoflagellate of euryhaline and eurythermal characteristics, widely distributed in tcmpcrate coastal and estuarine zones [34]. In the Urdaibai estuary, however, it was only conspicuous in the 15-20 range during the 1994 study period.

In some estuaries, the outer euhaline area is the zone of maximum phytoplankton biomass and production. This is generally explained in terms of a higher light availability in this outer zone $[10,25]$. In the Urdaibai estuary, however, in the outer area tidal flushing is maximum, as a result of which both nutrient concentration and phytoplankton biomass are low. Neritic diatoms and dinoflagellates dominate the phytoplankton assemblage in this zone and small flagellates are also abundant, but they do not experience massive accumulations.

In coastal waters it has been observed that high $\mathrm{N}: \mathrm{Si}$ ratios favour the development of nondiatom phytoplankton relative to diatoms $[26,30]$ and so a possible relationship between $\mathrm{N}: \mathrm{Si}$ ratios and total diatom cell concentration:total nondiatom cell concentration ratios was investigated in the present study. However, no significant correlation was found between these two parameters for any of the stations sampled. Nevertheless, this lack of correlation can be partly due to the large variability in cell size among the different taxa, which makes the cell number unsuitable to calculate a biomass ratio of diatoms to nondiatoms. 


\section{Acknowledgements}

This work was funded by the Department of Education, Universities and Research of the Basque government (GV 118.310-0047/93) and the University of the Basque Country (UPV 118.310-EA213/93). M. Revilla was sup- ported by a grant from the Department of Education, Universities and Research of the Basque government. We also wish to thank Astilleros de Murueta S.A. for letting us use their shipyard facilities during the surveys. Two anonymous reviewers provided constructive comments.

\section{REFERENCES}

[1] Belcher J.H., Swale E.M.F., Skeletonema potamos (Weber) hasle and Cyclotella atomus hustedt (Bacillariophyceae) in the plankton of rivers in England and France, Br. Phycol. J. 13 (1978) 177-182.

[2] Borkman D.G., Turner J.T., Plankton studies in Buzzards Bay, Massachusetts, USA. II. Nutrients, chlorophyll $a$ and phaeopigments, 1987 to 1990, Mar. Ecol. Prog. Ser. 100 (1993) 27-34.

[3] Cloern J.E., Tidal stirring and phytoplankton bloom dynamics in an estuary, J. Mar. Rcs. 49 (1991) 203-221.

[4] Cloern J.E., Phytoplankton bloom dynamics in coastal ecosystems: a review with some general lessons from sustained investigation of San Francisco Bay, California, Rev. Geophys. 34 (1996) 127-168.

[5] Cloern J.E., Cole B.E., Wong R.L.J., Alpine A.E., Tempora] dynamics of estuarine phytoplankton: a case study of San Francisco Bay, Hydrobiul. 129 (1985) 153-176.

[6] De Sève M.A., Diatom blooms in the tidal freshwater zone of a turbid and shallow estuary, Rupert Bay (James Bay, Canada), Hydrobiol. 269/270 (1993) 225-233.

[7] Fisher T.R., Harding L.W. Jr., Stanley D.W., Ward L.G., Phytoplankton, nutrients and turbidity in the Chesapeake, Delaware, and Hudson Estuaries, Estuar. Coast. Shelf S. 27 (1988) $61-93$.

[8] Genkal S.I., Kiss K.T., Morphological variability of the diatom Cyclotella atomus Husted var. atomus and C. atomus var. gracilis var. nov, Hydrobiol. 269/270 (1993) 39-47.

[9] Haigh R., Taylor J.R., Sutherland T.F., Phytoplankton ecology of Sechelt Inlet, a fjord system on the British Columbia coast ol. I. General features of the nano- and microplankton, Mar. Ecol. Prog. Ser. 89 (1992) 117-134.

[10] Harding L.W. Jr., Long-term trends in the distribution of phytoplankton in Chesapeake Bay: roles of light, nutrients and streamflow, Mar. Ecol. Prog. Ser. 104 (1994) 267-291

[11] Ioriguchi T., Pienaar R.N., Ultrastructure of a marine dinoflagellate, Peridinium quinquecorne Abé (Peridiniales) from South Africa with particular reference to its chrysophyte endosymbiont, Bot. Mar. 34 (1991) 123-131.

[12] Horstmann U., Observations on the peculiar diurnal migration of a red tide dynophyceae in tropical shallow waters, J. Phycol. 16 (1980) 481-485.

[13] Iriarte $\Lambda$., Diaz F., Madariaga I. de, Revilla M., Orive E., Plankton metabolism during blooming and non-blooming conditions in a shallow estuary, Verh. Internat. Limnol. (in press).

[14] Iriarte A., Madariaga I. de, Diez-Garagarza F., Revilla M., Orive E., Primary plankton production, respiration and nitrification in a shallow temperate estuary during summer, J. Exp. Mar. Biol. Ecol. 208 (1996) 127-151.

[15] Jackson R.H., Williams P.J. le B., Joint I.R., Freshwater phytoplankton in the low salinity region of the river Tamar estuary, Estuar. Coast. Shelf S. 25 (1987) 290-311.

[16] Jeffrey S.W., Humphrey G.F., New spectrophotometric equations for determining chlorophyll $a, b, c l$ and $c 2$ in higher plants, algae and natural phytoplankton, Biochem. Physiol. Pflanzen. 167 (1975) 191-194.

[17] Jenkinson I.R., Estuarine plankton of Co Limerick. I. A recurrent summer bloom of the dinoflagellate Glenodinium foliaceurn stein confined to the Deel estuary, with data on microplankton biomass, Irish Nat. J. 23 (1990) 173-180.

[18] Klarer D.M., Millie D.F., Regulation of phytoplankton dynamics in a Laurentian Great Lakes estuary, Hydrobiol. 286 (1994) 97-108.

[19] Madariaga I. de, Uhertasun aldakuntzak Gernikako estuarioan, Elhuyar 15 (1989) 8-12.

[20] Madariaga I. de, Photosynthetic characteristics of phytoplankton during the development of a summer bloom in the Urdaibai estuary, Bay of Biscay, Estuar. Coast. Shelf S. 40 (1995) $559-575$.

[21] Madariaga I. de, Diez-Garagarza F, Revilla M., Caracterización hidrográfica del estuario de Urdaibai durante el desarrollo de una floración fitoplanctónica estival, Kobie 22 (1994) 13-21.

[22] Marshall H.G., Alden R.W., A comparison of phytoplankton assemblages in the Chesapeake and Delaware estuaries (USA), with emphasis on diatoms, Hydrobiol. 269/270 (1993) $251-261$.

[23] Orive E., Franco J., Ruiz A., Importancia del fitoplancton cn estuarios meso-macromareales someros: el ejemplo del estuario de Urdaibai, in: Angulo E. (Ed.), Urdaibai: investigación básica y aplicada, Gobierno Vasco, 1995, pp. 57-74.

[24] Paerl H.W., Nuisance phytoplankton blooms in coastal, estuarine and inland waters, Limnol. Oceanogr. 33 (1988) 823-847.

[25] Pennock J.R., Sharp J.H., Temporal alternation between lightand nutrient-limitation of phytoplankion production in a coastal plain estuary, Mar. Ecol. Prog. Ser. 111 (1994) 275-288. 
[26] Ragueneau O., De Blas Varela E., Tréguer P., Quéguiner B., Del Amo Y., Phytoplankton dynamics in relation to the biogeochemical cycle of silicon in a coastal ecosystem of western Europe, Mar. Ecol. Prog. Ser. 106 (1994) 157-172.

[27] Riaux C., Grall J.R., Hydrologie et biomasse phytoplanctonique dans un estuaire de Bretagne Nord, La Penzé, İnt. Rev. Ges. Hydrobio. 67 (1982) 387-404.

[28] Rijstenbil J.W., Bakker C., Jackson R.H., Merks A.G.A., de Visscher P.R.M., Spatial and temporal variation in community composition and photosynthetic characteristics of phytoplankton in the upper Westerschelde estuary (Belgium, SW Netherlands), Hydrobiol. 269/270 (1993) 263-273.

[29] Ruiz A., Franco J., Orive E., Suspended particulate matter dynamics in the shallow mesotidal Urdaibai estuary (Bay of Bizcay, Spain), Neth. J. Aquat. Ecol. 28 (1994) 309-316.

[30] Schöllhorn E., Granéli E., Influence of different nitrogen to silica ratios and artificial mixing on the structure of a summer phytoplankton community from the Swedish West Coast (Gullmar Fjord), J. Sea Res. 35 (1996) 159-167.
[31] Schuchardt B., Schirmer M., Phytoplankton maxima in the tidal freshwater reaches of two coastal plain estuaries, Estuar. Coast. Shelf S. 32 (1991) 187-206.

[32] Sharp J.H., Cifuentes L.A., Coffin R.B., Pennock J.R., Wong K.-C., The influence of river variability on the circulation, chemistry, and microbiology of the Delaware, Estuaries 9 (1986) 261-269.

[33] Smetacek V.S., Impact of freshwater discharge on production and transfer of materials in the marine environment, in: Skreslet S. (Ed.), The Role of Freshwater Outflow in Coastal Marine Ecosystems, NATO ASI Series, Springer-Verlag, Berlin, 1986, pp. 85-106.

[34] Sournia, A., Belin C., Berland B., Erard Le Denn E., Gentien P., Grzebyk D., Marcaillou-Le Baut C., Lassus P., Partensky F., Le phytoplankton nuisible des Côtes de France. De la biologie à la prévention, IFREMER (1991) 154.

[35] Strickland J.D.H., Parsons T.R., A practical handbook of seawater analysis, Bull. Fish. Res. Bd. Can. 167 (1972) 1-311.

[36] Tyler M.A., Seliger H.H., Selection for a red tide organism: physiological responses to the physical environment, Limnol. Oceanogr. 26 (1981) 310-324. 